\title{
Verbal Politeness as an Important Tool of Diplomacy
}

\author{
Venera Nagimovna Yapparova ${ }^{1}$, Juliya Viktorovna Ageeva1 \& Adamka Pavol $^{2}$ \\ ${ }^{1}$ Kazan Federal University, Russia \\ ${ }^{2}$ Constantine the Philosopher University in Nitra, Russia \\ Correspondence: Venera Nagimovna Yapparova, Kazan Federal University, Russia. E-mail: \\ venera2306@mail.ru
}

Received: June 9, 2019

Accepted: August 25, 2019 Online Published: August 31, 2019

doi:10.5539/jpl.v12n5p57

URL: https://doi.org/10.5539/jpl.v12n5p57

\begin{abstract}
This article examines the notion of diplomatic courtesy and analyzes the ways of its language expression in Russian diplomatic discourse on the example of the speeches delivered by the Minister of Foreign Affairs of the Russian Federation Sergey Lavrov.

Diplomatic courtesy is considered by the authors as an integral part of the diplomatic language, which, being a component of the official business style, is characterized by standardization, normalization, lack of emotionality and neutrality. At the same time, the diplomatic language allows the use of language means that are not regulated by the diplomatic protocol, which act as euphemisms and allow expressing opinions on acute political problems without violating the existing rules of diplomatic communication.

The success of diplomatic communication is achieved with the help of universal speech formulas that serve as a means of manifesting courtesy and correspond to the standards of diplomatic communication. Such speech formulas themselves do not have legal force, but they have great moral and political power, since they contribute to the regulation of the nature of relations between countries.

The article shows that diplomatic courtesy can be both positive and negative. The degree of courtesy in a diplomat's speech may depend on a wide range of various factors conditioned by the dependence of diplomatic etiquette on the specifics of interaction between communicants.

Based on the results of the conducted research, the authors came to the conclusion that during various meetings the Minister of Foreign Affairs uses the following verbal means - speech formulas of greeting, address, compliment, invitation, gratitude, condolence, farewell. The frequency of such speech formulas is explained by the need of abidance of an international protocol that prescribes to diplomatic staff a certain sequence of verbal and non-verbal actions.
\end{abstract}

Keywords: diplomatic discourse, etiquette, politeness, speech formula, diplomatic language

\section{Introduction}

The most important instrument of diplomacy is language, which serves not only as a means of fulfilment of the state foreign policy, but also as an instrument for maintaining world order and prosperity.

The importance of the diplomatic language is recognized by scientists from different fields of science who are engaged in researching various aspects of international communication, from ancient times to our days.

Diplomatic language, being a kind of official-business style of speech, has all the characteristics inherent in this style: neutrality, terminology, accuracy, standardization, and lack of emotion.

In diplomacy there are strict language frames that prescribe the choice of a certain type of lexical units and determine the style of communication. These rules should simplify international communication, promote the demonstration of maximum peacefulness and benevolence, as well as mutual respect and recognition. However, despite the fixed and universal diplomatic discourse at the present stage of the development of diplomatic activity, the language used by diplomats is not strictly limited in terms of choice of verbal means. This is explained by the fact that every state is particular in its historical development, socio-economic structure, national and cultural traditions, which cannot help reflecting in the language. That is why in the communication of representatives of different countries, in addition to international terminology and universal speech formulas, 
there are specific national elements that must be taken into account in the process of international diplomatic communication.

\section{Methods}

The empirical basis of the study is the verbatim records of the Minister of Foreign Affairs of the Russian Federation Sergey Lavrov, published in 2016-2018 on the official website of the Ministry of Foreign Affairs of the Russian Federation - http://www.mid.ru/press_service/minister_speeches. The analysis of the typewritten speeches made it possible to identify the most typical speech formulas used during the meetings and various statements of the minister, as well as to identify those evaluative tools that act as euphemisms and allow communicants to express their opinion on topical political issues without violating the diplomatic protocol and observing the norms diplomatic courtesy.

\section{Results and Discussion}

One of the necessary components of international communication is speech etiquette, its knowledge and observance is a necessary condition for business and personal communication of diplomats. The existence of speech etiquette allows you to regulate the speech behavior of communication participants by using stereotyped and stable formulas. In the opinion of IA. Romanova, "speech etiquette lies in speech courtesy, which finds expression in the formulas and norms of communication fixed in culture. So, in each culture for most situations (for example, making an apology, parting, etc.), there are codified speech rules and courtesy formulas ".

Thus, in the diplomatic language of different countries there will be both standardized international phrases and unique individual language elements that do not contradict the generally accepted international standards of diplomatic communication and allow preserving of state values. The values of diplomacy mean observance of the principles of a sovereign state, the resolution of conflict issues by peaceful means and diplomatic means.

The main instruments of diplomats' interaction are the diplomatic language, in the system of which prepared and automatically reproduced language formulas are relevant in different communicative situations and provide the effectiveness of communication in global interaction. The effectiveness of diplomatic communication, in its turn, provides the strategic nature of diplomatic discourse. According to O.S. Issers, "speech strategy is a complex of speech actions aimed at achieving a communicative goal", to which the diplomatic protocol and ceremonial, prescribing the rules of behavior and communication in the diplomatic community, largely contribute.

A positive result in the process of diplomatic communication is achieved by observing the principle of politeness, which involves the use of etiquette speech formulas in different communicative situations and at all stages of international communication.

The peculiarity of the implementation of etiquette in general and diplomatic etiquette, in particular, is that it can be realized only within the framework of communicative interaction. "The etiquette situation is always communicative. Etiquette is a dialogue, even if the participants in this dialogue are separated by space or space and time ".

The use of protocol formulas of diplomatic courtesy is the fundamental characteristic of the lexical composition of the diplomatic language. The pragmatics of the diplomatic language is manifested in the use of diplomatic appeals, protocol formulas of respect, which simultaneously express courtesy and respect for the business distance between communicants. Diplomatic courtesy manifests itself in both oral and written forms of diplomatic communication, and the category of courtesy is inextricably connected with the term of etiquette, since etiquette is understood as a formal courtesy, the observance of which is the desire to keep the distance between communicators.

In the opinion of V.V. Luneva, being the motivational basis of all communicative behavior, "politeness has two varieties: positive and negative. Negative (negative) politeness is aimed at minimizing impoliteness in the utterance and avoiding communicative conflict. Its function is to reduce aggression in communication, preserve freedom in actions, and maintain proper distance between communicants ". To do this, a whole arsenal of verbal and non-verbal strategies has been developed in the culture - indirectness in the expression of requests, euphemism and other ways of avoiding the name and discussion of unpleasant topics: We spoke frankly about all this. We, like our UN colleagues, are interested in maximally liberating our common efforts from casual, from what we call geopolitical games, and to concentrate on the fundamental interests of the Syrian people [http://www.mid.ru/ru/ press_service / minister_speeches // asset_publisher / 7OvQR5KJWVmR / content / id / 3181850]; It is sad that the US and its allies cynically use unfounded statements about the use of Damascus poisonous substances as an instrument of anti-Syrian geopolitical engineering 
[http://www.mid.ru/ru/press_service/minister_speeches/-assembly_publisher/7OvQR5KJWVmR/content/id/3102 270].

Positive politeness is connected with the maximum expression of respect and respect for the addressee and implements the tactics of reaching agreement [ibid.]: Dear Mr. Minister, Dear friends! We are glad to welcome you in Moscow. Russia is always configured to develop good-neighborly relations with the Democratic People's Republic of Korea. We have successfully developed inter-parliamentary contacts. We approve this [http://www.mid.ru/ru/press_service/minister_speeches//asset_publisher/7OvQR5KJWVmR/content/id/3161840]

The degree of manifestation of politeness can depend on various factors: the severity of the situation of communication, the rank of participants in communication, the social distance between them, the purpose of communication, etc. Thus, the use of courtesy in diplomatic communication, on the one hand, will show respect for the interlocutor, and on the other hand, demonstrate the importance of communication and its ultimate goal for the speaker: Russian President V.V. Putin appreciates the kind words that you expressed in your message on the occasion of his election to the next presidential term. He sends his best regards and best wishes concerning those major efforts that are now initiated on the Korean peninsula with your participation. $<\ldots>$ Come to Russia, we will be very glad to see you. [http://www.mid.ru/press_service/minister_speeches/-/asset_publisher/7OvQR5KJWVmR/content/id/3244581].

However, according to L.Yu. Chernyak, the use of diplomatic etiquette does not always depend on the willingness or unwillingness of the participants in the communication to show a friendly disposition, but "rather is an elementary necessity because of the habitual nature of such actions in international relations" [Chernyak 137]. For example, when addressing the interlocutors: Dear Mr. Secretary of State, Dear Colleagues, I saw you on February 16 in Bonn, where I had an opportunity to acquaint you with Moscow's main approaches to the agenda of Russian-American relations and to international affairs [http: //www.mid.ru/en/press_service/minister_speeches/-/asset_publisher/7OvQR5KJWVmR/content/id/2725202].

Thus, the diplomatic etiquette, according to L.Yu. Chernyak, "is a set of rules of behavior of international diplomatic communication subjects, which do not have legal force and unconditionally obligatory nature, based on traditional, unprotected forms of international communication and moral and ethical imperatives, in order to implement the principle of international courtesy and presented in the form of action or inaction of state officials. That is, diplomatic etiquette is an international almost-habit based on moral and ethical norms with the aim of creating and maintaining mutually polite, respectful relations in the international sphere ".

In the analyzed texts peculiar expressions or special discursive formulas accepted in diplomatic communication are common. "Special attention," Popov notes, "is paid to the form, first of all, to conversion, the final compliment, the correct spelling of the name of the addressee and his title". These formulas vary depending on the addressee of the message, its content, genre, but in each separate case the rules regulate the whole form of the document or form that are necessary for use in a conversation of one type or another.

Analysis of the stenograms of speeches by the Minister of Foreign Affairs of the Russian Federation, S. Lavrov, showed that most often in his speech the diplomat uses the following types of etiquette formulas: appeal, greeting, congratulation, invitation, gratitude, compliment, sympathy, condolences, farewell.

These etiquette formulas are the most frequent, because they represent the most important element of international meetings. Diplomats, observing the international protocol, should use similar speech clichés in their speech, because they give a tone for further dialogue, establish a positive atmosphere, emphasize the status and significance of the interlocutor.

Thus, the diverse nature of the meetings and speeches of Russian Foreign Minister Sergey Lavrov determines the use of speech clichés of various groups:

- address: Dear Mikhail Vasilievich, Excellencies, Ladies and Gentlemen, Colleagues, friends ... [http://www.mid.ru/ru/press_service/minister_speeches//asset_publisher/7OvQR5KJWVmR/content/id/2736414] ;

- greeting: We are glad to welcome you in Moscow. Welcome again! [http://www.mid.ru/en/press_service/ minister_speeches/-/asset_publisher/7OvQR5KJWVmR/content/id/2729055]; I am glad to see you in good health and in a good mood. Faces are cheerful. I am sure that this will continue. [http://www.mid.ru/web/guest/meropriyatiya_s_uchastiem_ministra/-/asset_publisher/xK1BhB2bUjd3/content/id /3161350]. 
- congratulations: On behalf of all who are present and on my own behalf, I would like to warmly congratulate him and wish him success in his future activities [http://www.mid.ru/press_service/minister_speeches//asset_publisher/7OvQR5KJWVmR/content/id/2717916]; Dear Daur Vadimovich, I congratulate you, and all the employees of the Foreign Ministry of the Republic of Abkhazia, represented by, you with the 25th anniversary of the formation of the Ministry of Foreign Affairs! Warmly congratulating you and all your colleagues on the anniversary, I want to assure that the Ministry of Foreign Affairs of the Republic of Abkhazia can always count on the support of the Ministry of Foreign Affairs of the Russian Federation. [http://www.mid.ru/web/guest/maps/ab/-/asset_publisher/raC79Y6r2HN9/content/ id/3228931];

- compliment: Dear Vladimir Vladimirovich, Ladies and gentlemen, I would like to join the words of my colleague and friend of the Minister of Foreign Affairs of the Republic of Belarus V.V. Makeya about the special significance of our allied relations. The Republic of Belarus is our closest ally and strategic partner ... [http://www.mid.ru/press_service/minister_speeches/-/asset_publisher/7OvQR5KJWVmR/content/id/3236296].

- condolence: Of course, we send the sincerest words of condolence and compassion to Ira and to the children Nastya and Maxim, all relatives and friends of Vitaliy Ivanovich. Rest in peace [http://www.mid.ru/en/press_service/minister_speeches/-/asset_publisher/7OvQR5KJWVmR/content/id/265685 4]; I would like to reaffirm our solidarity with the head of the Philippines and the Philippine people and once again say the words of sympathy and condolences to the families and friends of the victims [http://www.mid.ru/web/guest/meropriyatiya_s_uchastiem_ministra/-assembly_publisher/xK1BhB2bUjd3/conte $\mathrm{nt} / \mathrm{id} / 2764520]$.

- wish: I wish the participants perfect victories, and the organizers and guests - vivid impressions, good mood and all the best [http://www.mid.ru/web/guest/foreign_policy/news/-/asset_publisher/cKNonkJE02Bw/content/id / 3234018].

- thanks: Once again, I would like to express personally my gratitude to the President of the Republic of Abkhazia RD Khajimba and other Abkhazian colleagues for their assistance in resolving the issues .... Thank you again for it [http://www.mid.ru/en/press_service/minister_speeches//asset_publisher/7OvQR5KJWVmR/ content/id/2732106]; Dear colleagues, let me, on your behalf, express our appreciation to our Uzbek friends, personally to the Minister of Foreign Affairs AHKamilov for hospitality, excellent conditions for our work [http://www.mid.ru/ru/press_service/minister_speeches//asset_publisher/7OvQR5KJWVmR/content/id/2717916.

\section{Summary}

As can be seen from the examples above, in the speech of the minister, the universal formulas for all people are frequent and are used in various communicative situations. These speech formulas represent the basis of a diplomatic language, which, as an instrument of diplomatic activity, is intended to facilitate the regulation of interstate relations. Common speech formulas allow to express benevolence, correctness, restraint, attention, mutual respect to participants in international communication. Despite the changes in the world community, the speech formulas remain an integral part of the diplomatic language, which has no legal force, but has a moral and political binding force for the implementation of states. It was noted that in the diplomatic language, it is possible to use verbal means that go beyond strict rules and contribute to expressing opinions on problematic issues.

\section{Conclusions}

Diplomatic courtesy is a large and important part of diplomatic activity that regulates the behavior of diplomats and other officials in relations with each other and at diplomatic events. On the one hand, the norms of diplomatic etiquette are conditional and are only standard rules. On the other hand, they have tremendous power to regulate the nature of relations between countries. That is why the identification and study of key speech formulas of diplomatic discourse seems relevant and up-to-date

\section{Acknowledgments}

The work is performed according to the Russian Government Program of Competitive Growth of Kazan Federal University.

\section{References}

George, Y. (1996). Pragmatics. Oxford University Press.

Issers, O. S. (2006). Kommunikativnye strategii i taktiki russkoj rechi. Izd. 4-e, stereotipnoe. M.: KomKniga.

Keith, H., \& Richard, L. (2010). The Practice of Diplomacy: Its Evolution, Theory and Administration (2nd ed.). Routledge. 
Palekha, E. S., \& Egorov, D. S. (2015). Language and culture: Components of a single process. Journal of Language and Literature, 6(1), 311-317.

Robin, L. (1990). Talking Power. The Politics of Language. Basic Books.

Safonova, S. G., \& Lukoyanova, Y. K. (2016). The teaching of speech etiquette in the course of russian as a foreign language. Modern Journal of Language Teaching Methods, Special Issue, 81-85.

Shakhmatova, T. S., \& Moskaleva, L. A., \& Cui, W. (2017). Grammatical realization of russian etiquette speech genres: the genre «request». J. Fundam. Appl. Sci., 9(7S), 1165-1173.

Watts, R. J. (2003). Politeness. Cambridge University Press. https://doi.org/10.1017/CBO9780511615184

Zhao, Y. L., Shulezhkova, S. G., Walter, H., Bochina, T. G., \& Kostina, P. M. (2017). Slogans Appeared During the Crimean Spring in the Political Discourse of Modern Russia. International Journal of Scientific Study, 5(5), 358-361.

\section{Copyrights}

Copyright for this article is retained by the author(s), with first publication rights granted to the journal.

This is an open-access article distributed under the terms and conditions of the Creative Commons Attribution license (http://creativecommons.org/licenses/by/4.0/). 